\title{
Legislation and policy changes for Tuberculosis Surveillance in Mongolia: A qualitative analysis
}

\section{Oyunchimeg Erdenee, Hiroshi Koyama}

Public Health, Graduate School of Medicine, Gunma University, Maebashi, Gunma, Japan

Objective

In order to track progress towards TB goals, we investigated the legal framework for disease surveillance, specifically policy changes for TB surveillance in Mongolia during the MDGs and the SDGs era.

\section{Introduction}

Mongolia is one of countries in the WHO Western Pacific Region with a high TB burden. The National Stop TB Strategy 20102015 implemented and developed strong surveillance and response system in the country. However, new TB incidence and deaths have not decreased significantly. Political commitment is critical for effective TB surveillance and that commitment can be demonstrated by a country's legal framework, which governs the practice of prevention and control. Therefore, this study is aimed at investigating the legal underpinnings for disease surveillance to help identify what policy changes have occurred in Tuberculosis surveillance.

\section{Methods}

We conducted a literature review that included government strategy, programme guidelines and procedures, to examine the overall disease surveillance system in Mongolia, and used a framework analysis to investigate operation of the TB surveillance system (CDC 2001 guideline). First, nine of core functions and six of support functions for the TB surveillance system were placed on the $\mathrm{Y}$ axis, and the national TB strategies, programme, guidelines and procedures were placed on the $\mathrm{X}$ axis. Next, the strategies, programme, guidelines and procedures were unpacked and allocated to cells based on whether they were consistent with the essential functions of the surveillance system. These data points were then used to develop a matrix to enable understanding of correspondence and changes between the legal documents during MDGs to SDGs.

\section{Results}

Result 1. Mongolia has an Emerging Disease Surveillance and Response unit and A National Centre for Communicable Disease responsible for implementing the International Health Regulations in the country. The legal framework for the surveillance system was updated regularly and overall, 11 legal instruments were identified.

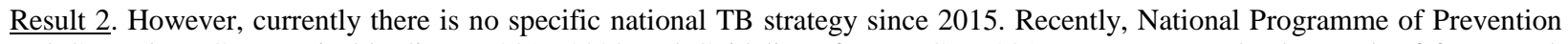
and Control on Communicable disease 2017-2020 and Guidelines for TB Care 2017 were approved. The result of framework analysis shows that during MDGs era, the legal documents had weaknesses that were related to "feedback" from the core and "training and resources" from the support functions. On other hand, the weaknesses of the legal documents for SDGs were related to "outbreak preparedness and response" from the core and "training and supervision" from the support functions.

\section{Conclusions}

There is an urgency to update the legal framework to enable a comprehensive strategy specifically for TB surveillance nationwide. Also, additional studies should be done continuously and should incorporate other parts of the assessment, including co-ordination, laboratories,to help determine the factors that influence the overall structure of Tuberculosis surveillance in the country. Legal instruments for disease surveillance in Mongolia. 


\begin{tabular}{|c|c|c|c|c|c|}
\hline Number & Focus & Legal Instrument & $\begin{array}{c}\text { Type of } \\
\text { document }\end{array}$ & $\begin{array}{r}\text { Year of } \\
\text { document }\end{array}$ & Purpose \\
\hline 1 & $\mathrm{CD}$ & $\begin{array}{l}\text { Strengthening } \\
\text { prevention and control } \\
\text { of hospital acquired } \\
\text { infections }\end{array}$ & $\begin{array}{l}\text { Ministerial } \\
\text { order \#336 }\end{array}$ & 1997 & $\begin{array}{l}\text { First complete legal document to control and reduce } \\
\text { hospital acquired infection in Mongolia }\end{array}$ \\
\hline 2 & $\mathrm{CD}$ & $\begin{array}{l}\text { National Programme for } \\
\text { Communicable Diseases }\end{array}$ & $\begin{array}{l}\text { Government } \\
\text { resolution } \\
\quad \# 129\end{array}$ & 2002 & $\begin{array}{l}\text { Mid-term directions for hospital acquired infection prevention } \\
\text { and control with estblishment of sentinel surveillance system } \\
\text { with improved laboratory-based monitoring. }\end{array}$ \\
\hline 3 & $\mathrm{CD}$ & $\begin{array}{l}\text { National programme on } \\
\text { prevention and control for } \\
\text { Communicable Diseases } \\
(2017-2021)\end{array}$ & $\begin{array}{l}\text { Government } \\
\text { resolution } \\
\# 11\end{array}$ & $\begin{array}{l}2017 \\
\text { (Updated } \\
\text { version of } \\
\text { 2002) }\end{array}$ & $\begin{array}{l}\text { Reduce the spread of infectious diseases by strengthening the } \\
\text { capacity of multi- sectors to strengthen surveillance, } \\
\text { prevention and mitigation of epidemics, and to provide } \\
\text { flexible, quality, accessible and prompt response to infectious } \\
\text { diseases. }\end{array}$ \\
\hline 4 & $\mathrm{CD}$ & $\begin{array}{l}\text { Strengthening } \\
\text { prevention and control } \\
\text { of hospital acquired } \\
\text { infections }\end{array}$ & $\begin{array}{c}\text { Ministerial } \\
\text { order \#85 }\end{array}$ & 2008 & $\begin{array}{l}\text { Ministry of Health replaced the previous infection control } \\
\text { guidelines with intention of moving closer towards } \\
\text { international standards }\end{array}$ \\
\hline 5 & $\mathrm{CD}$ & $\begin{array}{l}\text { Emerging Diseases and } \\
\text { Public Health } \\
\text { Emergencies (2012- } \\
\text { 2016) }\end{array}$ & $\begin{array}{l}\text { Ministerial } \\
\text { order \# }\end{array}$ & 2012 & $\begin{array}{l}\text { Aim is designed to strenghten preparedness planning, } \\
\text { prevention, early detection and rapid response to } \\
\text { emerging diseases and other public health emergencies }\end{array}$ \\
\hline 6 & NCD & $\begin{array}{l}\text { National Programme for } \\
\text { Non-Communicable } \\
\text { Diseases }\end{array}$ & $\begin{array}{l}\text { Government } \\
\text { resolution \# }\end{array}$ & 2005 & $\begin{array}{l}\text { Strengthen NCD prevention, screening and risk } \\
\text { management by population-based prevention systems and } \\
\text { participation and cooperation of organizations, } \\
\text { communities, the international community }\end{array}$ \\
\hline 7 & NCD & $\begin{array}{l}\text { National Programme for } \\
\text { Non-Communicable } \\
\text { Diseases }\end{array}$ & $\begin{array}{l}\text { Government } \\
\text { resolution \# }\end{array}$ & $\begin{array}{l}2013 \\
\text { (Updated } \\
\text { version of } \\
\text { 2005) }\end{array}$ & $\begin{array}{l}\text { Strengthen NCD prevention, screening and risk } \\
\text { management by population-based prevention systems and } \\
\text { participation and cooperation of organizations, } \\
\text { communities, the international community, }\end{array}$ \\
\hline 8 & NCD & $\begin{array}{l}\text { National Programme for } \\
\text { Non-Communicable } \\
\text { Diseases }\end{array}$ & $\begin{array}{l}\text { Government } \\
\text { resolution } \\
\quad \# 289\end{array}$ & $\begin{array}{l}2017 \\
\text { (Updated } \\
\text { version of } \\
\text { 2013) }\end{array}$ & $\begin{array}{l}\text { Strengthen NCD prevention, screening and risk } \\
\text { management by population-based prevention systems and } \\
\text { participation and cooperation of organizations, } \\
\text { communities, the international community, }\end{array}$ \\
\hline 9 & NCD & $\begin{array}{c}\text { Cancer registration and } \\
\text { surveillance }\end{array}$ & $\begin{array}{l}\text { Ministerial } \\
\text { order \#431 }\end{array}$ & 2014 & $\begin{array}{l}\text { National programme for cancer prevention, control, and } \\
\text { intervention through gathering analyzing, sharing, } \\
\text { informing about new incidence or deaths of cancer }\end{array}$ \\
\hline 10 & $\begin{array}{l}\text { Gener } \\
\text { al }\end{array}$ & $\begin{array}{c}\text { State Policy on Public } \\
\text { Health }\end{array}$ & $\begin{array}{l}\text { Parliament } \\
\text { Statement } \\
\quad \# 81\end{array}$ & 2001 & $\begin{array}{l}\text { The state policy on public health is to protect and promote the } \\
\text { health of the population by ensuring the harmony of nature, } \\
\text { human beings and society, to create favorable conditions for } \\
\text { living and working in healthy and safe environment. }\end{array}$ \\
\hline 11 & $\begin{array}{l}\text { Gener } \\
\text { al }\end{array}$ & Health Law & Law & 2011 & The purpose of this law is to define the state \\
\hline
\end{tabular}


Framework analysis for TB surveillance

\begin{tabular}{|c|c|c|c|c|c|c|c|}
\hline $\begin{array}{l}\text { Surveillance system } \\
\text { functions (CDC 2001) }\end{array}$ & \multirow{2}{*}{$\begin{array}{l}\text { Indicator of } \\
\text { the } \\
\text { government } \\
\text { documents }\end{array}$} & \multicolumn{2}{|c|}{$\begin{array}{l}\text { 6. Combat HIV/AIDS, malaria } \\
\text { and other diseases- Halt and } \\
\text { begin to reverse the incidence of } \\
\text { malaria and other major } \\
\text { diseases. }\end{array}$} & \multirow{2}{*}{$\begin{array}{c}\text { Reflectio } \\
\text { n of the } \\
\text { functions } \\
\text { for } \\
\text { MDGs }\end{array}$} & \multicolumn{2}{|c|}{$\begin{array}{l}\text { SDG era } \\
\text { 2030, end the epidemics of } \\
\text { erculosis, malaria and } \\
\text { pical diseases and combat } \\
\text { r-borne diseases and other } \\
\text { aunicable diseases }\end{array}$} & \multirow{2}{*}{$\begin{array}{c}\begin{array}{c}\text { Reflection } \\
\text { of } \\
\text { functions } \\
\text { for SDGs }\end{array} \\
\\
\text { Criteria } \\
\text { results }\end{array}$} \\
\hline I.Core functions & & $\begin{array}{l}\text { National } \\
\text { Programm } \\
\text { e for } \\
\text { combating } \\
\text { Communi } \\
\text { cable } \\
\text { disease } \\
\\
\\
(2002- \\
2010) \\
\end{array}$ & $\begin{array}{l}\text { National Strategy } \\
\text { on TB (2010-2015) }\end{array}$ & & $\begin{array}{c}\text { National } \\
\text { Programme of } \\
\text { Prevention and } \\
\text { Control on } \\
\text { Communicable } \\
\text { disease } \\
\\
\\
(\mathbf{2 0 1 7 - 2 0 2 0 )}\end{array}$ & $\begin{array}{l}\text { Guideline for TB } \\
\text { care / Minister } \\
\text { order A/306 } \\
\text { (2017)) }\end{array}$ & \\
\hline 1.Case detection & Purpose & $\begin{array}{l}\text { To reduce } \\
\text { the } \\
\text { prevalence } \\
\text { and } \\
\text { mortality } \\
\text { of } \\
\text { tuberculosi } \\
\text { s by } 2010 \\
\text { by } \\
\text { introducing } \\
\text { a direct } \\
\text { short-term } \\
\text { treatment } \\
\text { at all levels } \\
\text { of health } \\
\text { services }\end{array}$ & $\begin{array}{l}\text { Eliminate TB in } \\
\text { Mongolia defined as } \\
\text { an incidence rate of } \\
\text { fewer than } 1 \text { case } \\
\text { per } 1,000,000 \\
\text { population }\end{array}$ & yes & $\begin{array}{l}\text { Combat the spread } \\
\text { of communicable } \\
\text { disease prevention } \\
\text { and response, to } \\
\text { strengthen inter- } \\
\text { sectoral cooperation } \\
\text { and cooperation, } \\
\text { and to establish a } \\
\text { healthy behavior for } \\
\text { infectious diseases. }\end{array}$ & $\begin{array}{l}\text { 1.Management and } \\
\text { organization of } \\
\text { tuberculosis care } \\
\text { 2.Detection, } \\
\text { diagnosis and } \\
\text { treatment for drug } \\
\text { sensitive TB } \\
\text { 3.Detection, } \\
\text { diagnosis and } \\
\text { treatment for drug } \\
\text { resistant TB } \\
\text { 4.Detection, } \\
\text { diagnosis and } \\
\text { treatment for co- } \\
\text { infection of TB and } \\
\text { HIV 5.Routine } \\
\text { detection and } \\
\text { control of TB } \\
\text { contacts } \\
\text { 6.Guidelines for TB } \\
\text { control and } \\
\text { prevention } \\
\text { 7.Management } \\
\text { guideline for supply } \\
\text { of essential } \\
\text { products for TB } \\
\text { care }\end{array}$ & yes \\
\hline 2.Case confirmation & & & & yes & & $\begin{array}{l}\text { 8.Procedures for } \\
\text { registration and } \\
\text { reporting of } \\
\text { tuberculosis }\end{array}$ & yes \\
\hline 3.Case registration & & & & yes & & & yes \\
\hline 4.Case reporting & & & & yes & & & yes \\
\hline
\end{tabular}


ISDS 2019 Conference Abstracts

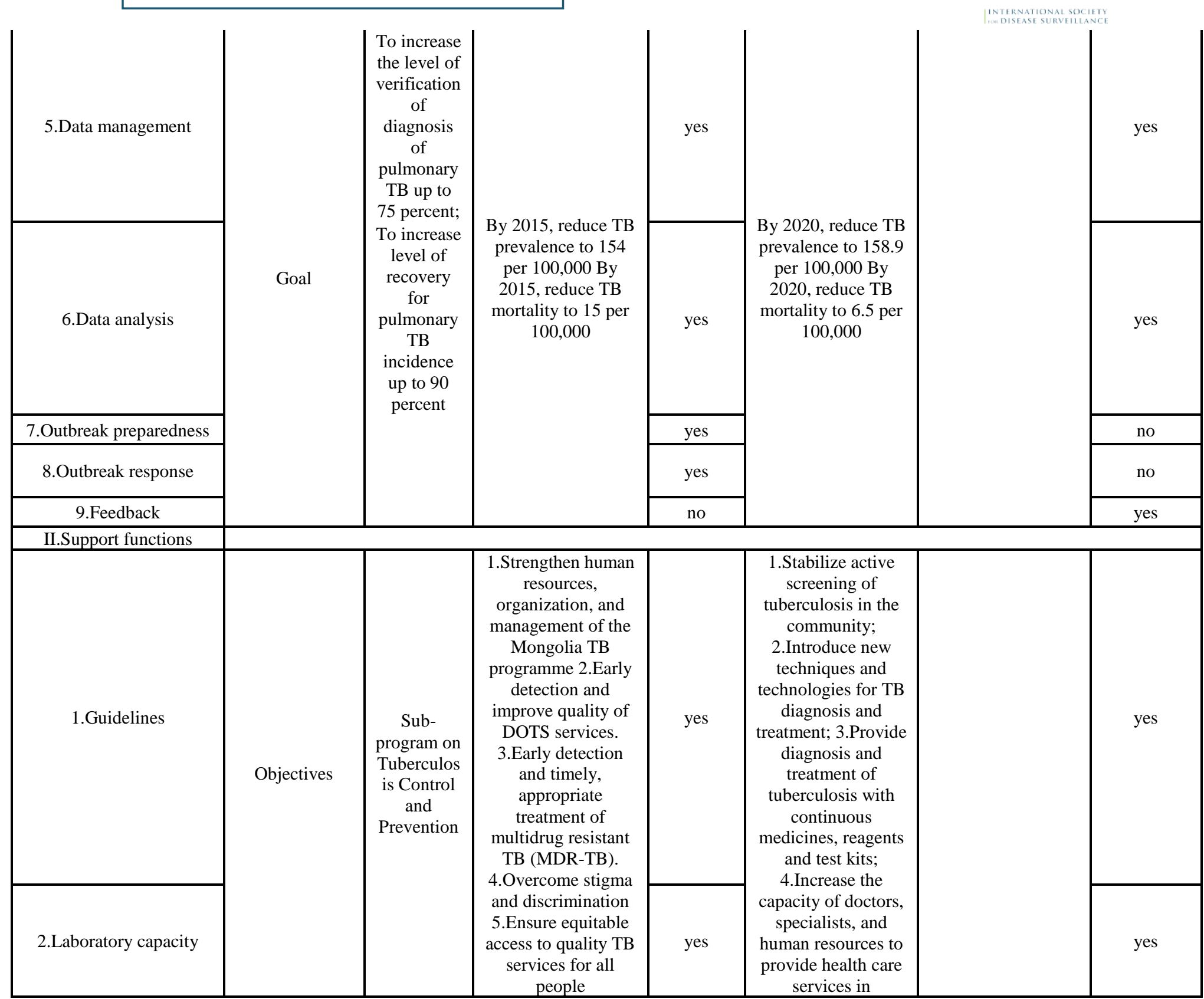


1.1 Advocacy to improve political commitment and development of supportive policy environment, 1.2 Strengthening information, monitoring and evaluation system, 1.3 Strengthening human capacity,

2.1 Early detection and treatment through strengthening laboratory services and other means 2.2 Support patients through treatment 2.3 Strengthening TB drug management 2.4

Engagement of nonNTP providers in

TB control (PublicPrivate Mix DOTS) 2.5 Improving coordination of TB/HIV collaborative activities 3.1

Expand programmatic management of MDR-TB 4.1

Behavior change communication 5.1 Improve access to DOTS in peripheral areas 5.2 Expansion of services for vulnerable populations tuberculosis, and create conditions

for them to

maintain their

employment;

5.Strengthen TB

surveillance system

and expand research and research.

6.Organize

advocacy work for policy makers and decision makers at the national and local levels to reduce

tuberculosis; Involve governmental and non-governmental organizations in social and psychological support for clients;

7.Increase access to

TB services through expanding community-based activities; Improving the prevention and control of infectious diseases of the health organization and creating a client-friendly environment;

8.Collaborate with the media to intensify the activities of providing health education to citizens and strengthening the right knowledge and attitudes. 